\title{
Antisense expression of Gossypium hirsutum UDP-glucuronate decarboxylase in Arabidopsis leads to changes in cell wall components
}

\author{
D.M. Zhang ${ }^{1 *}$, Y.X. Pan ${ }^{2 *}$, Y. Zhang ${ }^{1}$, Z.K. Li ${ }^{1}$, L.Q. Wu' ${ }^{1}$, H.W. Liu', G.Y. Zhang ${ }^{1}$, \\ X.F. Wang ${ }^{1}$ and Z.Y. Ma ${ }^{1}$ \\ ${ }^{1}$ North China Key Laboratory for Crop Germplasm Resources of Education \\ Ministry/Key Laboratory of Crop Germplasm Resources of Hebei, \\ Agricultural University of Hebei, Baoding, China \\ ${ }^{2}$ North China University Science and Technology, Tangshan, China \\ *These authors contributed equally to this study. \\ Corresponding authors: Z.Y. Ma / X.F. Wang \\ E-mail: mzhy@hebau.edu.cn / cotton@hebau.edu.cn \\ Genet. Mol. Res. 15 (1): gmr.15017409 \\ Received August 11, 2015 \\ Accepted November 9, 2015 \\ Published February 5, 2016 \\ DOI http://dx.doi.org/10.4238/gmr.15017409
}

\begin{abstract}
UDP-glucuronate decarboxylase (UDP-xylose synthase; UXS, EC 4.1.1.35) is an essential enzyme of the non-cellulosic polysaccharide biosynthetic pathway. In the present study, using transient expression of fluorescently labeled Gossypium hirsutum UXS (GhUXS3) protein in onion epidermal cells, we observed that this protein was distributed in the cytoplasm. The GhUXS3 cDNA of cotton was expressed in an antisense orientation in Arabidopsis thaliana by Agrobacterium tumefaciensmediated transformation. Homozygous plants showing down-regulation of UXS were analyzed with northern blots. Compared to the untransformed control, transgenic plant showed shorter roots, earlier blossom formation, and delayed senescence. Biochemical analysis indicated that levels of rhamnose, mannose, galactose, glucose, xylose, and cellulose
\end{abstract}


were reduced in some of the down-regulated antisense plants. These results suggest that GhUXS3 regulates the conversion of non-cellulosic polysaccharides and modulates their composition in plant cell walls. We also discuss a possible cellular function for GhUXS in determining the quality of cotton fibers.

Key words: Gossypium hirsutum; UDP-glucuronate decarboxylase; Transgenic Arabidopsis, Down-regulation; Cell wall changes

\section{INTRODUCTION}

The spinning quality of cotton (Gossypium hirsutum) depends much upon its fiber properties. These fibers are unicellular seed trichomes, developed from individual epidermal cells of the ovules. They are developed during four distinct, yet overlapping, phases, namely initiation, elongation (formation of primary cell walls), secondary cell wall biosynthesis, and maturation (Basra and Malik, 1984). Building a fiber matrix during the two middle phases requires the synthesis and cross-linking of abundant complex polysaccharides, including cellulose, hemicelluloses, and pectins. Because fiber strength is determined by this cellulosic and non-cellulosic network (Hsieh, 1999; Wilkins and Jernstedt, 1999), it is critical that researchers understand this process of formation and the related system for enzyme functioning. Although, numerous studies have been conducted on cotton fiber cellulose, little is known about the non-cellulose components, e.g., xylose, arabinose, galactose, rhamnose, xyloglucan, and pectin. These components are mainly involved in the metabolism of UDP-xylose, a key nucleotide sugar (Reiter and Vanzin, 2001). In cotton fibers, xylose and arabinose contents gradually increase until secondary cell wall synthesis begins (Meinert and Delmer, 1977).

UDP-xylose is derived from UDP-glucose in two steps: 1) UDP-glucose dehydrogenase (UGD, EC 1.1.1.22) catalyzes the formation of UDP-glucuronic acid (UDP-GlcA) from UDP-glucose, and 2) UDP-GlcA is irreversibly converted to UDP-xylose by UDP-glucuronic acid decarboxylase (UDP-xylose synthase; UXS, EC 4.1.1.35; Zhang et al., 2005). The UXS family belongs to the short-chain dehydrogenase/reductase superfamily (Moummou et al., 2012). In plants, different UXS isoforms occur in the cytosol and membrane-bound compartments (Harper and Bar-Peled, 2002).

UXS has a central role in sugar nucleotide inter-conversion. The first UXS was cloned from a fungus, Cryptococcus neoformans (Bar-Peled et al., 2001). Its activity has now been reported in other microorganisms, vertebrate species, and plants. From various species of bacteria, 826 predicted UXS enzymes have been identified, suggesting that xylose is more prevalent in bacterial glycans (Coyne et al., 2011). In zebrafish, UXS1 activity is essential for functional deposition of proteoglycans in the extracellular matrix (Eames et al., 2010). The crystal structure, molecular dynamics, and response pathways of UXS have also been analyzed in humans (Eixelsbergeret al., 2012). At least five UXS protein isoforms have been isolated from Arabidopsis (Harper and BarPeled, 2002), while UXS has been cloned from pea (Pisum sativum) seedlings (Kobayashi et al., 2002). Six UXS genes have been detected in rice (Suzuki et al., 2004). In tobacco, several UXSs have been purified and expressed in tissues associated with secondary wall formation. Downregulation of some of these genes by antisense expression has been associated with reduced xylan contents in such tissues (Bindschedler et al., 2007).

We previously isolated three UXS genes, GhUXS1 to 3, from cotton (Pan et al., 2010). Their roles in affecting the biosynthesis of cell wall polysaccharides and fiber traits are not well 
understood. Because GhUXS3 lacks the N-terminal extension found in the other two, we have been investigating its functioning. This gene has a 1038-bp open reading frame (ORF) and encodes a protein of 345 amino acids, with a calculated molecular mass of $38.98 \mathrm{kDa}$. Sequence alignment revealed that this protein contains a highly conserved motif of the UXS family.

Arabidopsis is a powerful model system for studying cell wall biosynthesis and the functions of various cell wall polymers (Liepmanet al., 2010). Therefore, we used an Arabidopsis knockout mutant for GhUXS3 to determine the role of individual GhUXS enzymes and to test the function of this gene during cell wall formation in plants.

\section{MATERIAL AND METHODS}

\section{Subcellular localization of GhUXS3 and GFP fusion proteins expressed in onion epidermal cells}

Forsubcellular localization of GhUXS3 protein, we transiently expressed pCamE-UXS3:GFP fusion protein in live onion epidermal cells. GhUXS3 was fused to the pCamE:GFP expression vector under the control of a constitutive CaMV 35S promoter, upstream of the GFP sequence. The coding region of GhUXS3 contained digestion sites for Xball and Kpnl restriction enzymes (TaKaRa, China). After amplification with primers 5'-TCTAGAATGGCGACAGATTCATCAAATGG-3' and 5'-GGTACCCTCTTCAGAGATTCCAAGCCTC-3' (restriction sites underlined), the polymerase chain reaction (PCR) product and the pCamE:GFP plasmid were purified, digested with Xball and $K p n l$, and ligated using $\mathrm{T}_{4} \mathrm{DNA}$ ligase (NEB, America). The correct-sized recombinant pCamEUXS3:GFP and the control pCamE-GFP plasmids were transferred into the epidermal cells using a gene gun (PDS-1000/He Particle Delivery System; Bio-Rad, USA), according to the manufacturer instructions. The transformed cells were incubated on Murashige and Skoog (MS) agar plates under darkness at $25^{\circ} \mathrm{C}$ for 36 to $48 \mathrm{~h}$. Thereafter, we examined the localization of the GFP fusion protein and the control pCamE-GFP under blue light with a fluorescence microscope (Olympus BX51, Japan).

\section{Growing of Arabidopsis thaliana plants}

Seeds of $A$. thaliana ecotype 'Columbia-0' were placed on plates in dark for 2 to 4 days at $4^{\circ} \mathrm{C}$ to break their dormancy. The vernalized seeds were germinated in a greenhouse under a $16-\mathrm{h}$ photoperiod and $60-70 \%$ relative humidity. The resultant plants that reached the bolting stage and formed floral inflorescences were used in the transgenic experiments.

\section{Construction of plant antisense-expression vectors and Arabidopsis transformation}

The GhUXS3 coding sequence was PCR-amplified from its cDNA Sall and Xbal site was introduced at the 5'- and 3'-end of the ORF, respectively. The amplifications were performed with primers 5'-GAGCTCGATGGCGACAGATTCATC-3' and 5'-GCTCTAGACTCTTCAGAGATTCCAA GCCTC-3' (restriction sites underlined). The PCR product was cloned into pGM-T vector (TIANGEN, China). The plasmid DNA containing an accurate GhUXS3 ORF was digested with Sall and $X$ bal. It was then sub-cloned in the antisense orientation at the corresponding sites in the expression vector, pBI121, to generate a pBI121:GhUXS3 chimeric construct under the control of the constitutive $35 \mathrm{~S}$ promoter. 
The authenticated construct was transferred into Agrobacterium tumefaciens strain GV3101 and cultured for 2 days at $28^{\circ} \mathrm{C}$ on a Luria broth selective medium containing $100 \mathrm{mg} / \mathrm{L}$ kanamycin and $50 \mathrm{mg} / \mathrm{L}$ streptomycin. The transformed bacteria were used to infect 'Columbia-0' plants by the floral-dip method (Clough and Bent, 1998). The primary transformants $\left(T_{1}\right)$ were collected from the regenerated $T_{0}$ plants, and the $T_{1}$ seeds were selected on a $1 / 2$-strength MS selective medium supplemented with $100 \mathrm{mg} / \mathrm{L}$ kanamycin. The PCR positive $T_{1}$ seeds were selfpollinated to obtain homozygous $T_{2}$ transformants. After sowing, selection, and self-pollination of $\mathrm{T}_{2}$ transformants, $\mathrm{T}_{3}$ plants were obtained. Only those lines showing kanamycin resistance were considered homozygous and were selected for further analyses.

\section{Northern blot analysis of GhUXS3}

The expression of GhUXS3 mRNA in transgenic Arabidopsis was analyzed by northern blot analysis. Total RNA was extracted from positive $T_{3}$ transgenic lines and one 'Columbia- 0 ' wild-type (WT) control plant, using TRIZOL reagent (TransGen, China). The extracted RNA was combined with $8 \mu \mathrm{L}$ formaldehyde and $5 \mu \mathrm{L}$ 10X MOPS (morpholinopropanesulfonic acid, $200 \mathrm{mM}$ MOPS, $50 \mathrm{mM}$ sodium acetate, $20 \mathrm{mM}$ EDTA, $\mathrm{pH} \mathrm{7.0)} \mathrm{and} \mathrm{heated} \mathrm{at} 65^{\circ} \mathrm{C}$ for $10 \mathrm{~min}$. Thereafter, the samples were cooled on ice for $5 \mathrm{~min}, 6 \mu \mathrm{L} 10 \mathrm{X}$ loading buffer was added to them and they were separated on agarose gels containing 10X MOPS. The electrophoresed RNA was transferred by capillary blotting onto Hybond $\mathrm{N}^{+}$nylon membranes (Amersham Pharmacia, USA). Probes for the RNA gel blot were PCR-amplified from the pBI121:GhUXS3 chimeric vector with the primers 5'-CCCCACCCACGAGGAGCAT-3' and 5'-TCCATCCACAACCCGAGACATACT-3'. The digoxigenin-labeling of the probe, its denaturation, and northern blot analysis were performed with a DIG DNA Labeling and Detection Kit II (Roche, Germany) according to the manufacturer instructions. The membranes were hybridized overnight at $42^{\circ} \mathrm{C}$ and washed twice, for $20 \mathrm{~min}$ each, in 2 X SSC and $0.1 \%$ SDS followed by two washes with $0.5 X$ SSC and $0.1 \%$ SDS at $65^{\circ} \mathrm{C}$; the membranes were subsequently exposed to X-ray film.

\section{Phenotypic analysis of transgenic Arabidopsis lines}

After surface-sterilization with antiformin, seeds of the positive $T_{3}$ transgenic lines and the WT control were germinated on plates containing non-selective $1 / 2$-strength MS. Root lengths were measured from one-week-old plants of all the genotypes. After another five weeks, we evaluated the performance of the transgenics and WT by comparing the floral stem and rosette leaf characteristics of these six-week-old plants.

\section{Cell wall preparation and analysis}

\section{Cell wall extraction}

Arabidopsis cell walls were isolated according to the method of Diet et al. (2006). Six weeks after germination, 3-g samples of stems and leaves from transgenic seedlings were homogenized with a mortar and pestle under liquid nitrogen followed by rapid addition of $30 \mathrm{~mL} 70 \%$ ethanol. The homogenate was centrifuged at $2683 \mathrm{~g}$ for $5 \mathrm{~min}$ at $4^{\circ} \mathrm{C}$, and the supernatant was discarded. The above steps were repeated twice. A 20-mL 1:1 (v:v) chloroform:methanol mixture was added and the supernatant was centrifuged at $2683 \mathrm{~g}$ for $5 \mathrm{~min}$ at $4^{\circ} \mathrm{C}$ three times. The resulting cell wall 
residues were washed three times in $100 \%$ acetone and air-dried. The residues were sequentially incubated overnight with $\alpha$-amylase ( $5 \mathrm{U} / \mathrm{mg}$ sample) and DMSO to eliminate the starch completely. The deposit was washed three times in ultrapure water and once in $100 \%$ acetone.

\section{Analysis of non-cellulosic monosaccharides}

The non-cellulosic monosaccharides in the air-dried cell wall residues were analyzed by HPLC (high performance liquid chromatography); 1-phenyl-3-methyl-5-pyrazolone (PMP) was used for pre-column-derivatization (Fu and O'Neill, 1995; Rozaklis et al., 2002). Standard samples of rhamnose (Rha), mannose (Man), galactose (Gla), glucose (Glc), and xylose (Xyl) were dissolved in water, diluted to a concentration of $3.6 \mathrm{~g} / \mathrm{L}$, and used as the internal standard. To $50 \mu \mathrm{L}$ standard solutions, $50 \mu \mathrm{L} 0.6 \mathrm{M} \mathrm{NaOH}$ and $100 \mu \mathrm{L} 0.5 \mathrm{M} \mathrm{PMP}$ was added. The mixture was heated at $70^{\circ} \mathrm{C}$ for $100 \mathrm{~min}$, cooled for $10 \mathrm{~min}$, and acidified with $10 \mu \mathrm{L}$ hydrochloric acid. It was then extracted twice with the same volume of $1: 1(\mathrm{v}: \mathrm{v})$ chloroform:methanol mixture before being centrifuged at $10,000 \mathrm{rpm}$ for $5 \mathrm{~min}$. To ensure that the excess PMP had been completely removed, the extraction was repeated twice. The aqueous phase was passed through a $0.22-\mu \mathrm{m}$ filter membrane and injected into a Promosil C18 column (Shimadzu LC-20AB, Japan) at $40^{\circ} \mathrm{C}$. The mobile phase, which was a mixture of ammonium acetate $(\mathrm{pH} 5.5)$ and acetonitrile (70:30, v/v), was used at a flow rate of $1.0 \mathrm{~mL} / \mathrm{min}$; the sample injection volume was $20 \mu \mathrm{L}$, and the detection was done at $254 \mathrm{~nm}$.

A mixture of cell wall residues (5 $\mathrm{mg}$, described above) and $1.5 \mathrm{~mL} 2$ MTFA (methyl trifluoroacetic acid) was hydrolyzed at $121^{\circ} \mathrm{C}$ for $2 \mathrm{~h}$. Following air-drying, $500 \mu \mathrm{L} 0.3 \mathrm{M} \mathrm{NaOH}$ was added and the solution was centrifuged at $10,000 \mathrm{rpm}$ for $10 \mathrm{~min}$. The supernatant $(100 \mu \mathrm{L})$ was combined with $100 \mu \mathrm{L} \mathrm{PMP}$, the mixture was incubated at $70^{\circ} \mathrm{C}$ for $100 \mathrm{~min}$ and cooled. The treated product was then neutralized, extracted, filtered, and analyzed by HPLC following the method described above for preparing the monosaccharide internal standard solution.

\section{Analysis of cellulose concentration}

The level of cellulose in Arabidopsis cell walls was determined by acolorimetric method using anthrone reagent (Updegraff, 1969). Briefly, $5 \mathrm{mg}$ treated cell wall residue was boiled for 30 min with an 8:1:2 (v:v:v) mixture of acetic acid:nitric acid: $\mathrm{H}_{2} \mathrm{O}$. The sample was cooled and centrifuged at $4000 \mathrm{rpm}$ for $5 \mathrm{~min}$ at $4^{\circ} \mathrm{C}$. The pellet was washed with $\mathrm{H}_{2} \mathrm{O}$ and then with acetone before being air-dried. It was then dissolved in $72 \%(\mathrm{v} / \mathrm{v}) \mathrm{H}_{2} \mathrm{SO}_{4}$ for $1.5 \mathrm{~h}$ at room temperature (RT), diluted 10 times with $72 \% \mathrm{H}_{2} \mathrm{SO}_{4}$, and centrifuged. A mixture of $100 \mu \mathrm{L}$ supernatant and $900 \mu \mathrm{L}$ ultrapure water was prepared, to which $2 \mathrm{~mL}$ anthrone was added rapidly. After rapid cooling, the mixture was boiled for $15 \mathrm{~min}$, transferred back to ice, and kept at RT for 5 to $10 \mathrm{~min}$. Absorbance of the sample was measured at $620 \mathrm{~nm}$ with a Beckman DU800 spectrophotometer (Beckman, Ameica). The results were compared with a standard curve of glucose (produced simultaneously) to calculate the concentration of cellulose.

\section{RESULTS}

\section{Cytoplasmic localization of GFP-fused GhUXS3}

Onion epidermal cells transformed with the pCamE:GFP vector displayed green fluorescence in the nucleolus and plasma membrane (Figure $1 \mathrm{~A}$ ). Cells transformed with pCamE- 
UXS3:GFP showed fluorescence in the mesh structure around the perinuclear region (Figure 1B) and intracellular vesicular structures (Figure 1C). This pattern of distribution indicated that GhUXS3 encoded a cytoplasmic protein. Harper and Bar-Peled (2002) also reported that UDP-Xyl biosynthesis occurred in both the cytosol and membrane-bound compartments.

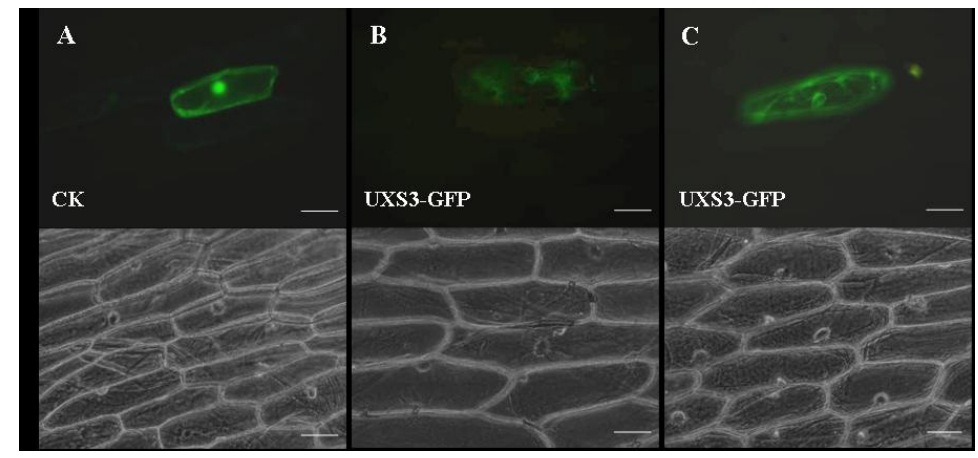

Figure 1. Subcellular localization of GhUXS3 fused with GFP in onion cells. Images of green fluorescence for pCamE:GFP vectors (A), and pCamE UXS3:GFP vectors (B, C). Bright-field images of cells are shown in lower panels. Scale bars $=20 \mu \mathrm{m}$.

\section{Expression analysis of GhUXS3 antisense-transgenic Arabidopsis plants}

To gain further insights into the function of GhUXS3 during Arabidopsis development, we constructed a recombinant plasmid, pBI121:GhUXS3 (Figure 2). Using digoxigenin-labeling, we generated a 750-bp GhUXS3 probe from the pBI121:GhUXS3 chimeric construct (Figure 3). The transgene was detected in three transgenic lines (AU3-16-13, AU3-22-1, and AU3-26-2) using northern blot analysis; the three independent $T_{3}$ transgenic lines had a similar degree of expression, with antisense-GhUXS3 transcript levels being higher than those detected in the WT (Figure 4). These results demonstrated that the antisense GhUXS3 was transcribed steadily in the transgenic Arabidopsis plants.

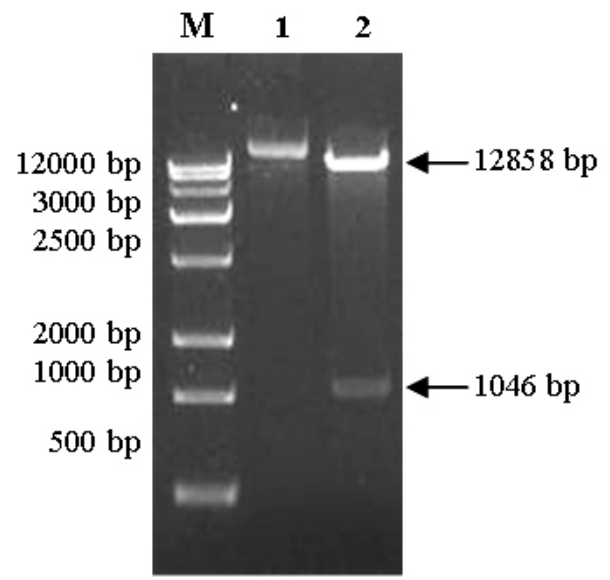

Figure 2. Characterization of antisense expression vector $\mathrm{pBI} 121$ : GhUXS3. Lane $M=$ wide molecular weight marker 500-12,000 bp; lane 1 = pBI121:GhUXS3 plasmid; lane 2 = pBI121:GhUXS3 plasmid digested with Sall and Xbal. 


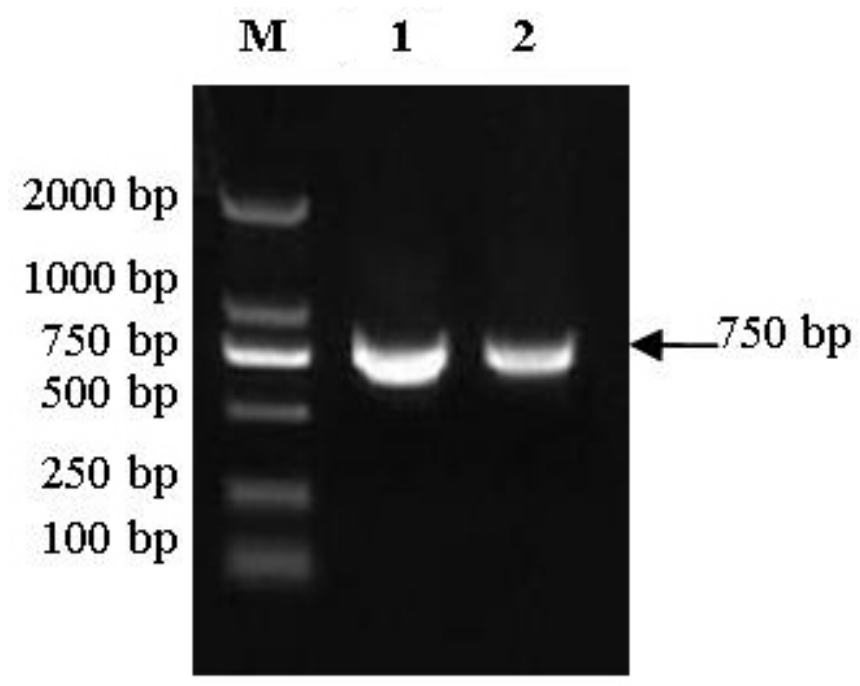

Figure 3. Antisense GhUXS3-amplified probe for northern blotting. Lane M, DL2000 molecular weight marker; lane 1 = template DNA; lane 2 = probe of antisense GhUXS3.

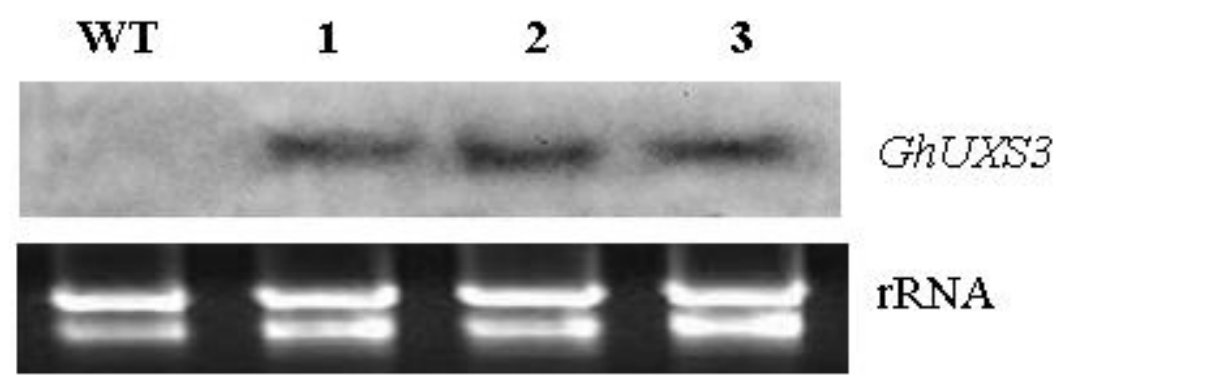

Figure 4. Northern blot analysis of $\mathrm{T}_{3}$ transgenic Arabidopsis plants with pBI121:GhUXS3. Lane WT = 'Columbia-0' wild-type control; lanes 1 to 3, transgenic lines AU3-16-13, AU3-22-1, and AU3-26-2, respectively.

\section{Phenotypic alteration of $T_{3}$ lines}

To characterize the possible roles for GhUXS3 in plants, we examined the three transgenic Arabidopsis lines that expressed antisense-GhUXS3 and noted their distinctive features compared to the WT. Root lengths differed significantly after 7 days of development (Figure 5), with those of transgenic lines being $7 \%(4.77 \pm 2.26)$ to $30 \%(3.60 \pm 2.30 \mathrm{~mm})$ shorter than those of the WT $(5.15 \pm 2.31$; Table 1$)$.

Antisense-expression of GhUXS3 continued throughout the 85- to 90-day lifespan of the transgenic Arabidopsis, a period that was approximately 20 days longer than the 70 -day life span of the WT. The transgenic lines also bloomed earlier. For example, by day 35, the transformed plants had already flowered or bolted while the WT was still in the vegetative stage (Figure 6). 
WT

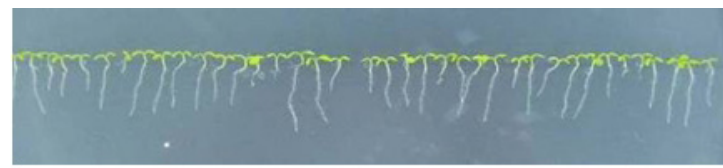

AU3-16-13

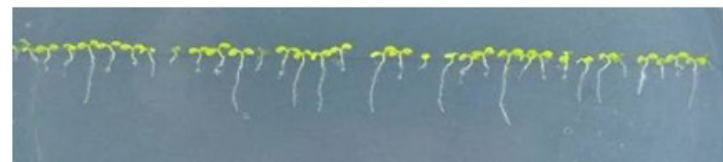

AU3-22-1

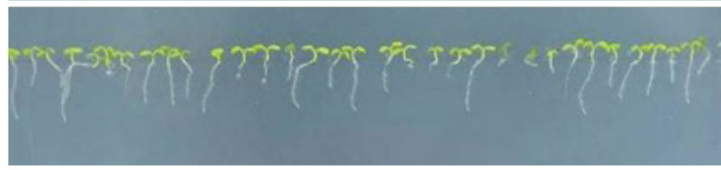

AU3-26-2

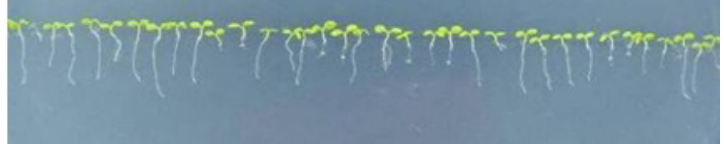

Figure 5. Roots of $\mathrm{T}_{3}$ transgenic Arabidopsis plants with antisense GhUXS3 after 7 days of growth.

Table 1. Growth characteristics of $\mathrm{T}_{3}$ Arabidopsis plants with expressing antisense GhUXS3.

\begin{tabular}{l|l|l|l|l}
\hline & WT & AU3-16-13 & AU3-22-1 & AU3-26-2 \\
\hline Length of floral stem $(\mathrm{cm})$ & $15.90 \pm 3.78$ & $27.90 \pm 2.86^{\star *}$ & $23.80 \pm 4.33^{\star *}$ & $16.80 \pm 3.87$ \\
\hline Diameter of floral stem $(\mathrm{mm})$ & $0.85 \pm 0.10$ & $1.02 \pm 0.08^{\star *}$ & $0.93 \pm 0.12^{\star *}$ & $0.82 \pm 0.08$ \\
\hline Length of rosette leaves $(\mathrm{mm})$ & $27.58 \pm 3.24$ & $31.32 \pm 2.55^{\star \star}$ & $30.05 \pm 4.34^{*}$ & $22.46 \pm 3.12$ \\
\hline Toughness of floral stem $(\mathrm{N})$ & $14.00 \pm 3.30$ & $18.30 \pm 4.70^{\star \star}$ & $18.50 \pm 4.30^{\star *}$ & $13.90 \pm 3.30$ \\
\hline
\end{tabular}

*Differences significant at the 0.05 level, ** differences significant at the 0.01 level (Two-tail $t$-test).

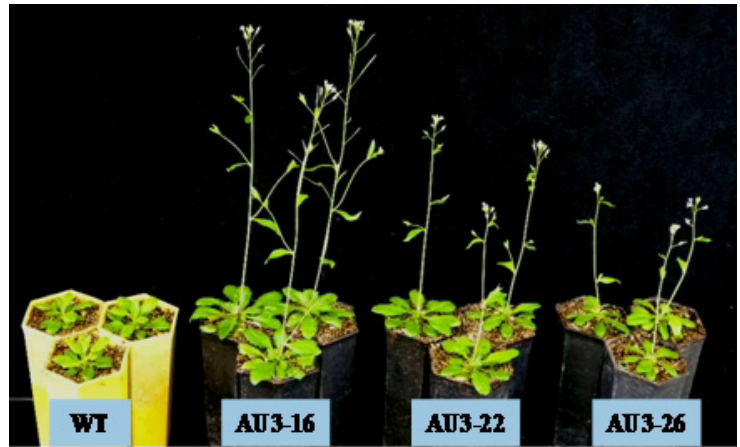

Figure 6. $\mathrm{T}_{3}$ transgenic Arabidopsis plants with antisense GhUXS3 after 5 weeks of growth.

After bolting, the stem lengths were $27.90 \pm 2.86 \mathrm{~cm}$ (AU3-16-13) and $23.80 \pm 4.33 \mathrm{~cm}$ (AU3-22-1), while the respective stem diameters were 20 and $9 \%$ larger (1.02 \pm 0.08 and 0.93 $\pm 0.12 \mathrm{~mm}$ for AU3-16-13 and AU3-22-1 versus $0.85 \pm 0.10 \mathrm{~mm}$ for the WT). Transgenic rosette leaves were also 2 to $4 \mathrm{~mm}$ longer than those of the WT. Toughness of floral stems increased more than $30 \%$ in those two transgenic lines (Table 1). In contrast, the third line, AU3-26-2, did not differ significantly from the WT in these phenotypic parameters. 


\section{Characterization of cell wall saccharides in antisense lines}

Because the loss of GhUXS3 functioning might have affected the availability of UDP sugars that are directly or indirectly derived from UDP-Xyl, we determined the compositions of sugar monomers in cell walls of the WT and transgenic plants using HPLC. The results revealed that Man, Rha, Gla, Glc, and Xyl concentrations were reduced in AU3-16-13 and AU3-22-1. In contrast, AU3-26-2 did not show significantly elevated concentrations of Man and Xyl when compared with the WT. The Glc/Xyl ratio in the cell walls from the antisense plants was 23.58 to $40.57 \%$ higher than in the controls (Table2). Using the colorimetric method, we found that the cellulose concentrations were significantly lower in the transgenics than in the control, by $16.35 \%$ for AU3-16-13, 28.30\% for AU3-22-1, and 30.50\% for AU3-26-2 (Figure7). This indicated that the cell wall components were modified in the antisense Arabidopsis plants.

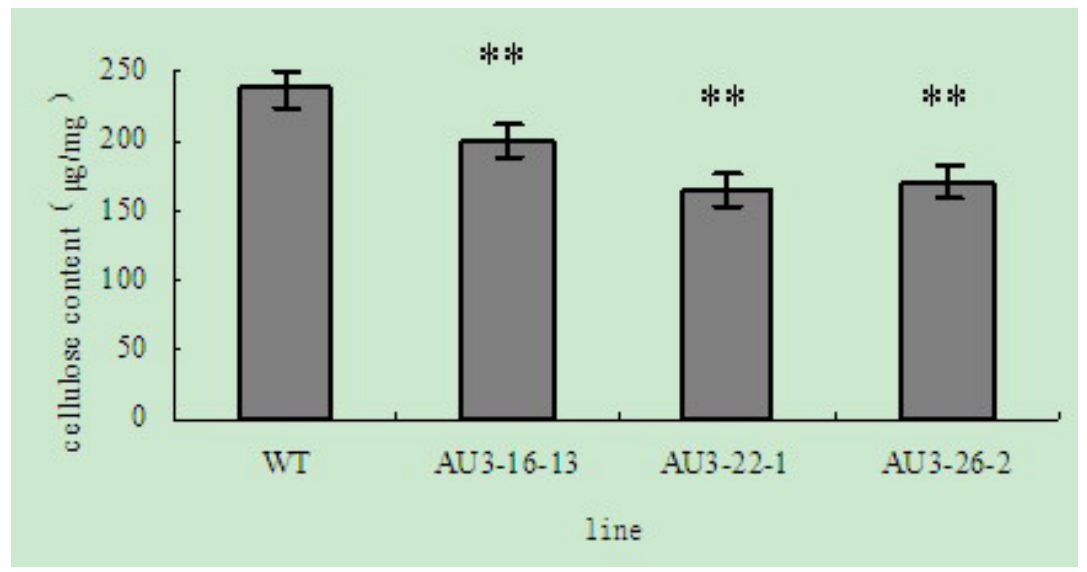

Figure 7. Cellulose concentration in the cell walls of $T_{3}$ transgenic Arabidopsis plants after 6 weeks of growth. ${ }^{* *}$ Significant differences at 0.01 level (Two-tail $t$-test with SPSS).

Table 2. Composition of cell wall saccharides ( $\mu \mathrm{g} / \mathrm{mg}$ cell wall) in Arabidopsis plants, as analyzed by HPLC.

\begin{tabular}{l|l|l|l|l|l|l}
\hline & Man & Rha & Gal & Glc & Xyl & Glc/Xyl \\
\hline WT & $4.15 \pm 0.73$ & $7.17 \pm 0.99$ & $1.97 \pm 0.45$ & $8.58 \pm 1.19$ & $8.09 \pm 1.89$ & 1.06 \\
\hline AU3-16-13 & $3.95 \pm 0.83$ & $7.01 \pm 2.79$ & $1.87 \pm 0.60$ & $4.93 \pm 0.19$ & $6.56 \pm 0.25$ & 0.75 \\
\hline AU3-22-1 & $3.33 \pm 1.42$ & $4.26 \pm 2.05$ & $1.12 \pm 0.47$ & $3.08 \pm 0.48$ & $3.78 \pm 0.21$ & 0.81 \\
\hline AU3-26-2 & $4.20 \pm 0.82$ & $6.52 \pm 1.22$ & $1.75 \pm 0.17$ & $6.38 \pm 1.10$ & $8.20 \pm 1.93$ & 0.78 \\
\hline
\end{tabular}

\section{DISCUSSION}

Many of the precursors for non-cellulosic polysaccharides are formed via UDP-Xyl, which is converted into pectin and hemicellulosic polysaccharides. Therefore, UXS has a crucial role for the conversion of diverse polysaccharides in the cell walls of plant, fungal, and bacterial glycans, and glycosaminoglycans in higher organisms (Reisset al., 1985; York and O'Neill, 2008; Coyne et al., 2011; Eixelsberger et al., 2012). At least three GhUXS genes are involved in the biosynthesis of fiber cell walls in cotton. Results from our previous reverse transcriptase-PCR analysis suggested that these genes were preferentially expressed during the different developmental stages, from 
elongation to secondary cell wall synthesis, with trace levels of transcripts being detected in the roots, hypocotyls, and leaves (Pan et al., 2010). Here, we confirmed that GhUXS3 encodes a cytoplasmic protein. We produced GhUXS3 down-regulated transgenics of Arabidopsis with altered metabolism of cell wall polysaccharides as well as a distinctly modified phenotype. These findings implicate the gene in cotton fiber development.

\section{Antisense expression of GhUXS3 causes alterations to phenotype and polysaccharide compositions}

Concentrations of Glc, Xyl, Man, Rha, and Gal were lower in AU3-16-13 and AU3-221 than in the WT. Antisense-transgenic tobacco also contained less Xyl when UXS was downregulated (Bindschedler et al., 2007). Thus, the observed decline in the Xyl levels was related to lower expression of GhUXS3. As a result, the indirect conversion of Man, Rha, and Gal from UDP-Xyl was also decreased. UDP-Xyl feedback can inhibit the upstream enzymes (UXS, UGD, and UDP-Glc pyrophosphorylase), thereby, controlling the flux for the conversion of UDP-Glc to UDP-GIcA, UDP-Xyl, UDP-Ara, and UDP-GalA in plants (Harper and Bar-Peled, 2002).

When UXS is down-regulated, the UDP-Xyl feedback inhibition of UGD may also disappear. This can cause increased activity of UGD, a greater accumulation of UDP-GlcA, and increased conversion of UDP-GIcA to UDP-galacturonic acid. A series of changes leads to the diversification of polysaccharide composition in the cell walls. Furthermore, antisense expression of GhUXS3 was manifested by longer floral stems and rosette leaves, tougher stems, and delayed senescence. These phenotypes contrast with those reported in the Arabidopsis mutant ugd2,3, in which a loss-of-function was associated with dwarfism and retarded development (Reboul et al., 2011). Because reduced UXS expression may enhance the UGD activity, it is possible that the reverse phenotype might occur with UXS and UGD mutants, thus confirming that GhUXS is active in cell wall development. Moreover, decreased expression of UXS was related to greater floral stem toughness and lower cellulose concentrations. Toughness is mainly reflected in the strength of the secondary cell wall; less cellulose means that mechanical strength is diminished (Hu and Han, 2008). Therefore, GhUXS can affect the quality of secondary cell walls.

In the present study, UDP-Glc and cellulose were reduced in the antisense GhUXS3 transgenic lines. Because UDP-Glc mainly produces UDP-Xyl and cellulose in plants, downregulation of GhUXS3 would result in a reduction in Glc and cellulose concentrations. We observed that the levels of Man, Xyl, Rha, and Gal were higher in one of our transgenic lines than in the WT. This might have arisen because of the differences in the insertion sites or because of functional redundancy among the members of the UXS gene family (Bindschedler et al., 2007).

\section{Speculative function of GhUXS3 in determining cotton fiber quality}

We previously proposed a model describing how GhUXS expression influenced fiber quality in cotton (Pan et al., 2010). UDP-XYL synthase 5 (UXS5) was down-regulated during the elongation stage in fuzzless-lintless ovules of a cotton fl mutant (Padmalatha et al., 2012). This evidence demonstrates that GhUXS3 is closely correlated with the formation of cotton fibers.

Cell wall polysaccharides influence cell division and growth; changes in the amounts of some of these components might trigger modifications in others (Ringli, 2010; Wallace and Anderson, 2012). Lignification and microfibril orientation are thought to be mediated by alterations in the amounts and distribution of non-cellulosic polysaccharides (Donaldson and Knox, 2012). 
Because fasciclin-like arabinogalactan proteins (FLAs) are related to pectin biosynthesis, GhFLA1 RNAi lines had more pectin, arabinose, and galactose, less hemicellulose and cellulose, and a significant reduction in their proportions of glucose when compared with the WT (Huang, et al., 2013). Our results demonstrated that the antisense GhUXS3 greatly altered the biochemical composition of cell walls, similar to the findings with the GhFLA1 RNAi lines. These modifications imply that GhUXS3 can affect pectin biosynthesis, stimulate changes in polysaccharide compositions, and influence cell wall development.

In conclusion, we propose that, when GhUXS3 expression is modulated, the conversion and the concentration of non-cellulosic polysaccharides is affected. A series of alterations can enhance the levels of both cellulosic and non-cellulosic polysaccharides, and change the cross-link structure, especially during the stages of elongation and secondary cell wall biosynthesis. Further studies need to be undertaken to clarify the mechanism by which GhUXS3 influences cotton fiber qualities.

\section{Conflicts of interest}

The authors declare no conflict of interest.

\section{ACKNOWLEDGMENTS}

Research supported by the National Basic Research Program of China (Grant \#2010CB126000), a project from the Ministry of Agriculture of China for Transgenic Research (Grant \#2011ZX08009-003), a Hebei Province Department of Education Fund (\#Y2012025), and a Hebei Province Technology Support Program (\#14962905D). The authors are grateful to Priscilla Licht for critical reading of the manuscript.

\section{REFERENCES}

Bar-Peled M, Griffith CL and Doering TL (2001). Functional cloning and characterization of a UDP- glucuronic acid decarboxylase: the pathogenic fungus Cryptococcus neoformans elucidates UDP-xylose synthesis. Proc. Natl. Acad. Sci. USA 98: 12003-12008.http://dx.doi.org/10.1073/pnas.211229198

Basra AS and Malik CP (1984). Development of the cotton fiber. Int. Rev. Cytol. 89: 65-113. http://dx.doi.org/10.1016/S0074-7696(08)61300-5

Bindschedler LV, Tuerck J, Maunders M, Ruel K, et al. (2007). Modification of hemicellulose content by antisense downregulation of UDP-glucuronate decarboxylase in tobacco and its consequences for cellulose extractability. Phytochemistry 68: 2635-2648.http://dx.doi.org/10.1016/j.phytochem.2007.08.029

Clough SJ and Bent AF (1998). Floral dip: a simplified method for Agrobacterium-mediated transformation of Arabidopsis thaliana. Plant J. 16: 735-743.http://dx.doi.org/10.1046/j.1365-313x.1998.00343.x

Coyne MJ, Fletcher CM, Reinap B and Comstock LE (2011). UDP-glucuronic acid decarboxylases of Bacteroides fragilis and their prevalence in bacteria. J. Bacteriol. 193: 5252-5259.http://dx.doi.org/10.1128/JB.05337-11

Diet A, Link B, Seifert GJ, Schellenberg B, et al. (2006). The Arabidopsis root hair cell wall formation mutant Irx1 is suppressed by mutations in the RHM1 gene encoding a UDP-L-rhamnose synthase. Plant Cell 18: 1630-1641. http://dx.doi.org/10.1105/tpc.105.038653

Donaldson LA and Knox JP (2012). Localization of cell wall polysaccharides in normal and compression wood of radiata pine: relationships with lignification and microfibril orientation. Plant Physiol. 158: 642-653. http://dx.doi.org/10.1104/pp.111.184036

Eames BF, Singer A, Smith GA, Wood ZA, et al. (2010). UDP xylose synthase 1 is required for morphogenesis and histogenesis of the craniofacial skeleton. Dev. Biol. 341: 400-415.http://dx.doi.org/10.1016/j.ydbio.2010.02.035

Eixelsberger T, Sykora S, Egger S, Brunsteiner M, et al. (2012). Structure and mechanism of human UDP-xylose synthase: evidence for a promoting role of sugar ring distortion in a three-step catalytic conversion of UDP-glucuronic acid. J. Biol. Chem. 287: 31349-31358.http://dx.doi.org/10.1074/jbc.M112.386706 
Fu D and O'Neill RA (1995). Monosaccharide composition analysis of oligosaccharides and glycoproteins by high-performance liquid chromatography. Anal. Biochem. 227: 377-384.http://dx.doi.org/10.1006/abio.1995.1294

Harper AD and Bar-Peled M (2002). Biosynthesis of UDP-xylose. Cloning and characterization of a novel Arabidopsis gene family, UXS, encoding soluble and putative membrane-bound UDP-glucuronic acid decarboxylase isoforms. Plant Physiol. 130: 2188-2198.http://dx.doi.org/10.1104/pp.009654

Hsieh YL (1999). Structural development of cotton fibers and linkages to fiber quality. In: Cotton fibers (Basra AS, eds.). Hawthorne Press Inc., New York, 137-144.

Hu P and Han TF (2008). Molecular basis of stem trait formation and development in plants. Chin. Bull. Bot. 25: 1-13.

Huang GQ, Gong SY, Xu WL, Li W, et al. (2013). A fasciclin-like arabinogalactan protein, GhFLA1, is involved in fiber initiation and elongation of cotton. Plant Physiol. 161: 1278-1290.http://dx.doi.org/10.1104/pp.112.203760

Kobayashi M, Nakagawa H, Suda I, Miyagawa I, et al. (2002). Purification and cDNA cloning of UDP-D-glucuronate carboxylyase (UDP-D-xylose synthase) from pea seedlings. Plant Cell Physiol. 43: 1259-1265. http://dx.doi.org/10.1093/pcp/pcf157

Liepman AH, Wightman R, Geshi N, Turner SR, et al. (2010). Arabidopsis - a powerful model system for plant cell wall research. Plant J. 61: 1107-1121.http://dx.doi.org/10.1111/j.1365-313X.2010.04161.x

Meinert MC and Delmer DP (1977). Changes in biochemical composition of the cell wall of the cotton fiber during development. Plant Physiol. 59: 1088-1097.http://dx.doi.org/10.1104/pp.59.6.1088

Moummou H, Kallberg Y, Tonfack LB, Persson B, et al. (2012). The plant short-chain dehydrogenase (SDR) superfamily: genome-wide inventory and diversification patterns. BMC Plant Biol. 12: 219.http://dx.doi.org/10.1186/1471-2229-12-219

Padmalatha KV, Patil DP, Kumar K, Dhandapani G, et al. (2012). Functional genomics of fuzzless-lintless mutant of Gossypium hirsutum L. cv. MCU5 reveal key genes and pathways involved in cotton fibre initiation and elongation. BMC Genomics 13: 624.http://dx.doi.org/10.1186/1471-2164-13-624

Pan YX, Wang XF, Liu HW, Zhang GY, et al. (2010). Molecular cloning of three UDP-glucuronate decarboxylase genes that are preferentially expressed in Gossypium fibers from elongation to secondary cell wall synthesis. J. Plant Biol. 53: $367-373$. http://dx.doi.org/10.1007/s12374-010-9124-9

Reboul R, Geserick C, Pabst M, Frey B, et al. (2011). Down-regulation of UDP-glucuronic acid biosynthesis leads to swollen plant cell walls and severe developmental defects associated with changes in pectic polysaccharides. J. Biol. Chem. 286: 39982-39992.http://dx.doi.org/10.1074/jbc.M111.255695

Reiss E, Huppert M and Cherniak R (1985). Characterization of protein and mannan polysaccharide antigens of yeasts, moulds, and actinomycetes. Curr. Top. Med. Mycol. 1: 172-207.http://dx.doi.org/10.1007/978-1-4613-9547-8 7

Reiter WD and Vanzin GF (2001). Molecular genetics of nucleotide sugar interconversion pathways in plants. Plant Mol. Biol. 47: 95-113.http://dx.doi.org/10.1023/A:1010671129803

Ringli C (2010). Monitoring the outside: cell wall-sensing mechanisms. Plant Physiol. 153: 1445-1452. http://dx.doi.org/10.1104/pp.110.154518

Rozaklis T, Ramsay SL, Whitfield PD, Ranieri E, et al. (2002). Determination of oligosaccharides in Pompe disease by electrospray ionization tandem mass spectrometry. Clin. Chem. 48: 131-139.

Suzuki K, Watanabe K, Masumura T and Kitamura S (2004). Characterization of soluble and putative membrane-bound UDPglucuronic acid decarboxylase (OsUXS) isoforms in rice. Arch. Biochem. Biophys. 431: 169-177. http://dx.doi.org/10.1016/j.abb.2004.08.029

Updegraff DM (1969). Semimicro determination of cellulose in biological materials. Anal. Biochem. 32: 420-424.http://dx.doi. org/10.1016/S0003-2697(69)80009-6

Wallace IS and Anderson CT (2012). Small molecule probes for plant cell wall polysaccharide imaging. Front. Plant Sci. 3: 89.http://dx.doi.org/10.3389/fpls.2012.00089

Wilkins TA and Jernstedt JA (1999). Molecular genetics of developing cotton fibers. In: Cotton Fibers (Basra AS, eds). Hawthorne Press Inc., New York, 231-267.

York WS and O'Neill MA (2008). Biochemical control of xylan biosynthesis - which end is up? Curr. Opin. Plant Biol. 11: 258265.http://dx.doi.org/10.1016/j.pbi.2008.02.007

Zhang Q, Shirley N, Lahnstein J and Fincher GB (2005). Characterization and expression patterns of UDP-D-glucuronate decarboxylase genes in barley. Plant Physiol. 138: 131-141.http://dx.doi.org/10.1104/pp.104.057869 